\title{
Salmonella Load in Rui Fishes and Suggestive Remedies in Cooking Process of Bangladeshi Dish
}

\author{
Sabira Sultana ${ }^{1}$, Bidduth Kumar Sarkar ${ }^{2}$, Prema Modak ${ }^{3}$ and Sukalyan Kumar Kundu ${ }^{4^{*}}$ \\ ${ }^{1}$ Department of Pharmacy, Jahangirnagar University, Savar, Dhaka, BANGLADESH \\ ${ }^{2}$ Department of Pharmacy, Ranada Prasad Shaha University, Narayanganj, BANGLADESH \\ ${ }^{3}$ Department of Pharmacy, Jahangirnagar University, Savar, Dhaka, BANGLADESH \\ ${ }^{4}$ Department of Pharmacy, Jahangirnagar University, Savar, Dhaka, BANGLADESH \\ *Corresponding author: S Sultana; E-mail: sabira.zoology@gmail.com
}

Received: 20 July, 2020

Revised: 20 Aug., 2020

Accepted: 07 Nov., 2020

\begin{abstract}
Bangladesh is a riverine country. At present we are $4^{\text {th }}$ top producer of fish in the world Rice and fish in our main food. Among fishes, Rui (Labeo ruhita) is the most popular and tasty fish for Bangladeshi people. The major fisheries sectors of Bangladesh support not only the domestic needs but also contributes to world export markets. It fulfills a major portion of the protein requirement of the general mass. Bangladeshi people cooks this fish in several ways, without marinate and marinate it will salt $\&$ turmeric powder and then fry it and boil it and making most of their daily dish. But a lot of Bangladeshi specially the children are infected by typhoid for which Salmonella sp. is responsible. Food is one of the carriers of Salmonella.
\end{abstract}

\section{HIGHLIGHTS}

(- Turmeric marinated Rui fish fried for 3 minutes at $400^{\circ} \mathrm{C}$ has no Salmonella.

( Salt marinated Rui fish fried for 15 minutes has no Salmonella.

(- Salt marinated Rui fish boiled for 10 minutes at $400^{\circ} \mathrm{C}$ has no Salmonella.

Keywords: Salmonellosis, Typhoid, Morbidity, Mortality, Pathogen, Enterocolitis, Contaminated

Fisheries sector plays an important role in food security, poverty alleviation and economic development of Bangladesh. Fisheries contribute $4.39 \%$ of our GDP, $22.76 \%$ of agricultural sector and $2.46 \%$ to foreign exchange earnings. Fish provides about $60 \%$ of national animal protein. Total fish production of Bangladesh was 32.62 lakh MT in 2011-12. But this year production may increase (www.flif.bd, 2012). Fish body maintains many types of bacterial flora in gills, gut and skin. After the death of fish these bacteria get favorable environment for rapid multiplication. The bacterial flora on fish reflects the aquatic environment which affects the quality and storage life of fishery products (Shewan, 1961). The quality of fish can be assessed by the degree of contamination with coliform bacteria. Contamination results mainly form rupturing of fish intestine during poor processing or unhealthy washing. Several studies have suggested that intestinal micro flora or contaminations by enteric bacteria of human or animal origin are responsible for spoilages (Geldreich, 1966). So, consumption of fish may cause disease due to infection or intoxication. It is believed to be the reflection of the general contamination in the aquatic environment. It is obvious that if the growing and harvesting environment of fish is polluted chemically or microbiologically, the fish will also be polluted (Boyd, 1985). For this reason, quality control of fish and fish products is very much important for consumer acceptance. For being highly perishable foodstuff, fish are

How to cite this article: Sultana, S., Sarkar, B.K., Modak, P. and Kundu, S.K. (2020). Salmonella load in Rui fishes and suggestive remedies in cooking process of Bangladeshi dish. J. Anim. Res., 10(6): 869-879. Source of Support: None; Conflict of Interest: None क क 
needed special care and attention from the catching site to the consumption table. Salmonella are motile rod and gram negative bacteria. Salmonella occurs commonly in domestic animals and birds. Contamination of fish with Salmonella is due to growth in polluted waters and poor handling, hygiene and sanitation standards after harvesting. The ability of salmonella to enter cultured epithelial cells is modulated by the bacterial growth state, such that bacteria growing under low-oxygen and high-osmolarity conditions are induced for invasion(Finlay,1989).Invasion of the intestinal epithelium is thought to be an important step in the pathogenesis of Salmonella infections. Using an in vitro system, we have isolated a genetic locus, inv, that confers to a noninvasive strain of Salmonella typhimurium the ability to penetrate tissue culture cells (Galan,1989). A ligated intestine model in calves, pigs, and rabbits was tested for its value as an indicator of virulence of potential vaccine strains of Salmonella typhimurium (Clarke, 1987). We have developed a novel ileal loop model for use in calves to analyze the contribution of Salmonella enteric serovar Typhimurium type III secretion systems to disease processes in vivo. Our model involves constructing ileal loops with end-to-end anastamoses to restore the patency of the small intestine, thereby allowing experimental animals to convalesce following surgery for the desired number of daysb (Coombes, 2005). Salmonella typhimurium infection is reviewed. Two patients had previous gastric operations, supporting previous reports that such patients are more susceptible to food poisoning. Four had no parietal (oxyntic) cells in the gastric mucosa, suggesting hypo- or anacidity. Only one had acute gastritis. None had acute enteritis, but in half of the patients, subtle histological changes suggested an 'enteropathy'. Acute diffuse colitis with abundant crypt abscesses, without stromal abscesses in the lamina propria, was the most constant finding and reparative features started very early, and occurred in later deaths. The pathology of the alimentary tracts of nine patients dying of prevalence of specific serovars of Salmonella enterica in human foodborne illness is not correlated with their prevalence in feed. Given that feed is a suboptimal environment for $S$. enterica, it appears that survival in poultry feed may be an independent factor unrelated to virulence of specific serovars of Salmonella (Boyd, 1969) (B. Malorny, 2011). The ability of salmonella to enter cultured epithelial cells is modulated by the bacterial growth state such that bacteria growing under low-oxygen and high-osmolarity conditions are induced for invasion (Franchi, 2006). Nontyphoid Salmonella are a common cause of bacterial gastroenteritis, which is usually a self-limiting illness in previously healthy adults (Fierer, 2001). Salmonella species cause a wide range of disease in multiple hosts. Salmonella enterica serovar Typhimurium causes self-limiting intestinal disease in humans and systemic typhoid-like illness in susceptible mice (Dybing, 1999). The stimulation of gamma interferon (IFN- $\gamma$ ) has been shown to be essential in resolving infections by intracellular pathogens. As such, several different cytokines including, interleukin-12 (IL-12) and IL-18 can induce IFN- $\gamma$. To resolve Salmonella infections, the stimulation of IL-12 and IFN- $\gamma$ are important for mediating its clearance. The relevance of IL-18 in protection against oral challenge with Salmonella typhimurium was investigated to determine the role of this IFN- $\gamma$-promoting cytokine (Dybing, 1999). The occurrence, distribution and persistence of coliform, fecal coliform and faecal streptococci in the intestinal tract of freshwater fish. Fecal coliform densities were lowest in blue gills (less than $20 / \mathrm{g})$ and highest in catfish $(1,090,000 / \mathrm{g})$ in that study. The occurrence of fecal coliform in fish caught in little Miami River reflected the warm-blooded animal polluted level of the water (Geldreich, 1966).

\section{MATERIALS AND METHODS}

\section{Bacteriological isolation}

Bacteria are isolated from Rui, fish samples of local markets. Bacteriological parameters for examination of fish samples were- SPC, qualitative analysis of Salmonella spp.

\section{Processing of fish samples}

Fish samples were taken out of the refrigerator \& thawed at room temperature. Then samples were cut $\& 20 \mathrm{~g}$ of each sample was blended with $180 \mathrm{ml}$ of sterile Bacteriological peptone water in a stomacher blender. Then $1 \mathrm{ml}$ of this $10^{-1}$ dilution was transferred to a screw cap vial containing $10 \mathrm{ml}$ of sterile dilute of Bacteriological peptone to make a dilution of $10^{-2}$. Then the vial was shaken gently. This process was repeated progressively to prepare of $10^{-3}, 10^{-4}$ \& $10^{-5}$. 


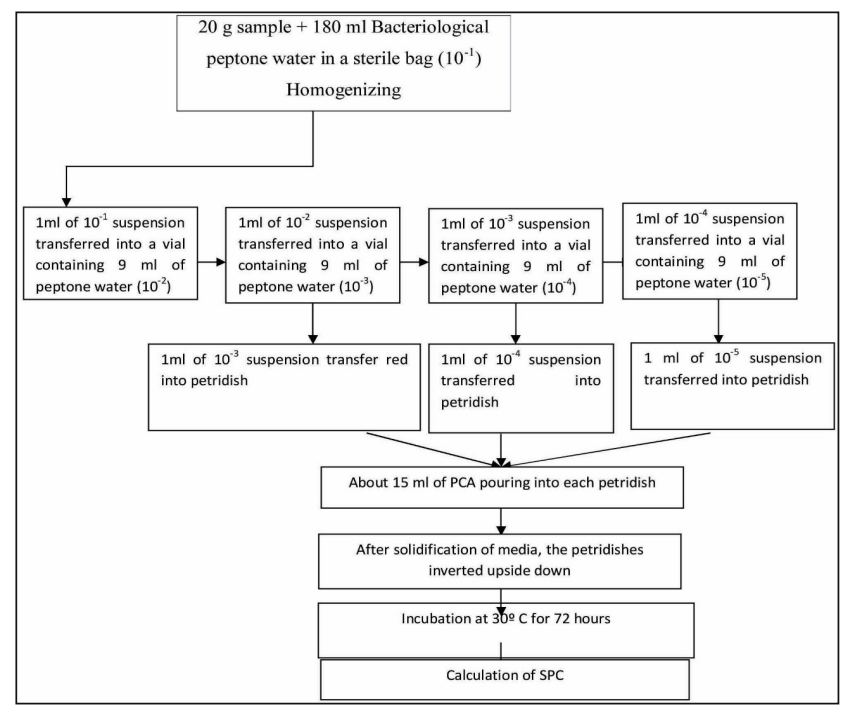

Diagram 1: Enumeration of Standard Plate Count (SPC)

\section{Detection of Salmonella in fresh fish (Negative control)}

Bangladesh is considered one of the most suitable regions for fisheries in the world, with the world's largest flooded wetland and the third largest aquatic biodiversity in Asia. Fish is a popular complement to rice in the national diet, giving rise to the adage Maache-Bhate Bangali ("a Bengali is made of fish and rice"). Rohu or rui is an important freshwater carp fish species. Rui fish farming is very common and popular in Bangladesh. Rui fish is very tasty and nutritious, and it has very good demand in the market. It is used in many occasions. Rui fish curry and fry both are very popular. Fish has also become a part of the rituals in Bengali tradition. The most commonly used fish to prepare this dish is a type of freshwater carp or rui maach. Bengali recipes call for the frying or boiling of the main ingredient in oil and marinated with salt and turmeric before it is added to the gravy or curry (boiling). In some Bengali homes, this frying translates to deepfrying, while in others it means pan-frying.

Turmeric powder is approximately $60-70 \%$ Carbohydrates, $6-13 \%$ water, $6-8 \%$ protein, $5-10 \%$ fat, $3-7 \%$ essential oils, $2-7 \%$ dietary fiber and $1-6 \%$ curcuminoids.

Salt is mostly sodium chloride. Salt is essential to the health of humans and other animals. Some people put a desiccant such as a few grains of uncooked food or a saltine cracker, in their salt shakers to absorb extra moisture and help break up salt clumps that may otherwise form. Fish has also become a part of the rituals in Bengali tradition.

It is customary in our country to marinate fish with salt or turmeric before cooking it. We chose Rui (small Rui locally called Nola), due to the fact that it is one of the most common source of our major nutrition, we had discovered Salmonella in our primary part of this research and tried to find out the load of Salmonella in this common fish. Considering the quantity of intake of Rui by the general mass, it is only logical to select this fish for our present research. We have collected four batches of fish weighing about 400 gm each from Fishery Firm of Government of Bangladesh, Baghhata, Norshingdi, Bangladesh.

In first stage we took without fry and boiling rui fish. But at the $2^{\text {nd }}$ stage we try to discover salmonella load from frying rui fish and the $3^{\text {rd }}$ stage from boiling rui fish.

After scrapping the fish, we had cut each fishes into 3 pieces and prepared 12 samples for lab test. The samples were taken to the lab for Salmonella Isolation test. Here, we took only $\mathrm{F}^{1}, \mathrm{~F}^{2}$ and $\mathrm{F}^{3}$. Lengths of the sample fishes are 2.1", 2.2" and 2.3", the width were 1.2", 1.2" and 1.01" while thickness of samples were more or less 1 " each respectively. The weights of the samples were between 45 gm to $60 \mathrm{gm}$.

For salmonella loaded test, I took samples $\mathrm{FL}^{1}, \mathrm{FL}^{2}$ and $\mathrm{FL}^{3}$. Length of the sample fishes are 2.9", 3.1" and 3.2" while the width were $1.5^{\prime \prime}, 1.3 "$ and $2.00^{\prime \prime}$ while thickness of samples were more or less 1 " each respectively. The weights of the samples were between $45 \mathrm{gm}$ to $60 \mathrm{gm}$.

\section{Processing}

Took $225 \mathrm{ml}$ buffered peptone water and 12 bottles each of which contained $9 \mathrm{ml}$ buffered peptone water. Performed autoclave for 15 minutes at $121^{\circ} \mathrm{C}$. Now, washed the samples with distilled water. Left the sample of 12 pieces for 15 minutes after applying $4 \mathrm{ml}$ of Salmonella in it .Each sample fish piece were cut into 3 smaller pieces. In total 12 sample pieces were cut into 36 pieces. These 36 pieces were divided into four groups- A, B. C and D. Fresh fish are marked as F I, F II and F III. $2 \% \mathrm{NaCl}$ solution marinated fish are marked as F I, F II and F III. Salmonella loaded Fresh fish are marked as FL I, FL II and FL III Prepared PCA media. 
Put, FL I, FL II and FL III and FL I, FL II and FL III in a sterile bag without marinating them. Kept all samples separately in a sterile tray and let them cool down to room temperature. After all the samples cooled down, left the samples in a refrigerator. In the refrigerator, at $4^{\circ} \mathrm{C}$ Bacteria will not grow in the sample but, salt and turmeric will interact. Took a sample in $225 \mathrm{ml} \mathrm{BP}$ in a sterile bag and blended in a Stomacher blender. Took $1 \mathrm{ml}$ from each sample for serial dilution. Incubated the sample for 24 hours at $37^{\circ} \mathrm{C}$. Added $1 \mathrm{ml}$ from each sample to MKTT. Incubated MKTT for 24 hours at $37^{\circ} \mathrm{C}$. Added $0.1 \mathrm{ml} \mathrm{RV}$ for each sample and kept in water bath at $42^{\circ} \mathrm{C}$ for 24 hours. Incubated it for 24 hours at $37^{\circ} \mathrm{C}$. Took the MKTT and RV with XLDA \& HEA plate. Afterwards incubated it for $18-24$ hours at $37^{\circ} \mathrm{C}$. Performed streaking process of MKTT and RV. Took the reading from XLDA and HEA. WI, WII, WIII \& OI, OII, OIII is also processing in this same way.

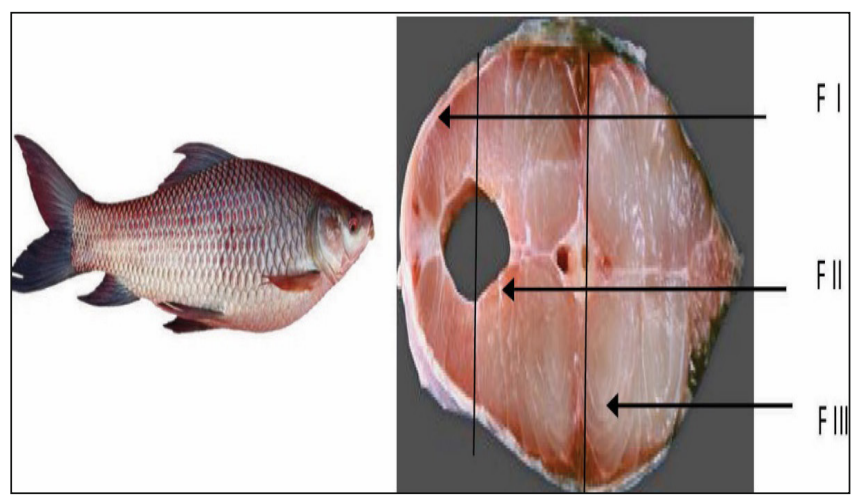

Fig. 1: Each sample fish was cut into 3 smaller pieces

\section{Impact of water boiling $\left(100{ }^{\circ} \mathrm{C}\right)$ after various kinds of fish processing}

It is customary in our country to marinate fish with salt or turmeric before boiling it or cooking it. We chose Rui (small Rui locally called Nola), due to the fact that it is one of the most common source of our major nutrition, we had discovered Salmonella in our primary part of this research and tried to find out the load of Salmonella in this common fish. Considering the quantity of intake of Rui by the general mass, it is only logical to select this fish for our present research. We have collected four batches of fish weighing about 400 gm each from Mohammadpur Krishi Market, Dhaka, Bangladesh.
After scrapping the fish, we had cut each fishes into 3 pieces and prepared 12 samples for lab test. The samples were taken to the lab for Salmonella Isolation test. Here, we took only WT I, WT II and WT III for water boiling. Lengths of the sample fishes are 2.0", 2.2" and 2.3", the width were 1.1", 1.2" and 1.01" while thickness of samples were more or less 1 " each respectively. The weights of the samples were between $45 \mathrm{gm}$ to $60 \mathrm{gm}$.

For boiled water + turmeric test, I took samples WT I, WT II and WT III. Length of the sample fishes are 2.9", 3.1" and 3.3" while the width were 1.5", 1.3" and 2.02" while thickness of samples were more or less 1 " each respectively. The weights of the samples were between 45 gm to $60 \mathrm{gm}$.

For boiled water + Salt test, I took samples WS I, WSII and WSIII. Length of the sample fishes are 3.3", 3.1" and 3.01" while the width was 1.3", 1.1" and 1.25" while thickness of samples were more or less $1 "$ each respectively. The weights of the samples were between $45 \mathrm{gm}$ to $60 \mathrm{gm}$.

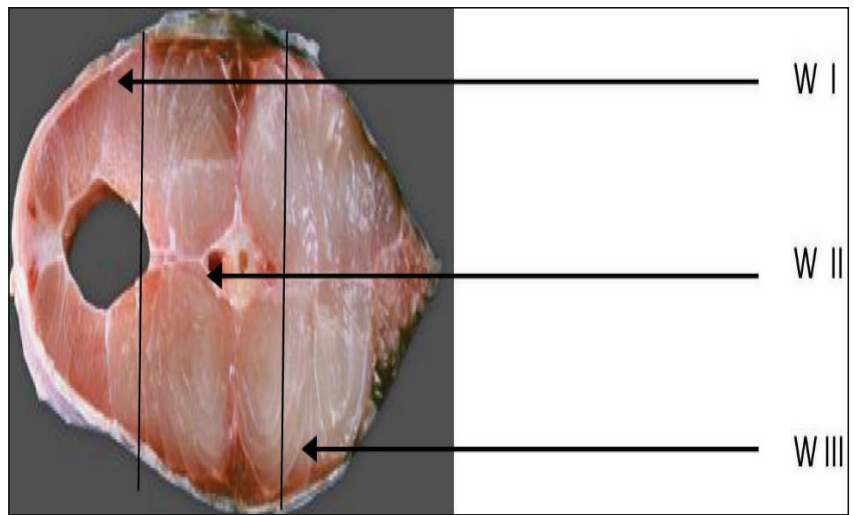

Fig. 2: Each sample fish was cut into 3 smaller pieces

For boiled water, turmeric + Salt test, I took samples WTS I, WTS II and WTS III. Length of the sample fishes are 2.4", 2.1" and 2.5" while the width was 1.3", 1.5" and 1.25" while thickness of samples were more or less 1 " each respectively. The weights of the samples were between 45 gm to $60 \mathrm{gm}$.

\section{Impact of oil fry $\left(400^{\circ}\right)$ after various kinds of fish processing}

Bangladesh is crisscrossed by rivers. Naturally, fish is one of our main foods along with rice. Fish is our main source of protein. If a study is made on which is the most 
consumed fish in this country, I believe Rui will become number one in the run. Fish is not only a favorite in the rural areas, it is also widely taken in the cities too. Generally, fish is marinated with salt and turmeric in our country before cooking as curry or fried in oil. Due to this reason, fried fish has been tested in different samples with states like:

$$
\begin{array}{ll}
\square & \text { Without marinated. } \\
\square & \text { Turmeric marinated. } \\
\square & \text { Salt marinated. \& } \\
\square & \text { Salt and turmeric marinated. }
\end{array}
$$

The tests will be performed to ascertain the load of Salmonella in all these different samples.

Bought 4 numbers Rui fish from Mohammadpur town hall market weighing approximately 400 gm each. Put on gloves before picking the fishes and brought them home in a sterile bag. Scrapped the fishes and cut each fish into 4 pieces (total 12 pieces). Took all 12 pieces to lab for Salmonella isolation. Took 3 pieces of fish to fry (no marinating), i.e. O I, O II, O III. Lengths of the samples were 2.1", 2.0" and 2.4". Widths were 1.2", 1.3", and 1.4". Weights of the samples were $51 \mathrm{gm}, 56 \mathrm{gm}$ and $60 \mathrm{gm}$.

For turmeric marinated sample, took OT I, OT II, OT III with length 1.8", 2.2" \& 2.6" and width were 1.3", 1.9" and 2.0" while weight of the samples were $50 \mathrm{gm}, 48 \mathrm{gm}$ and $52 \mathrm{gm}$

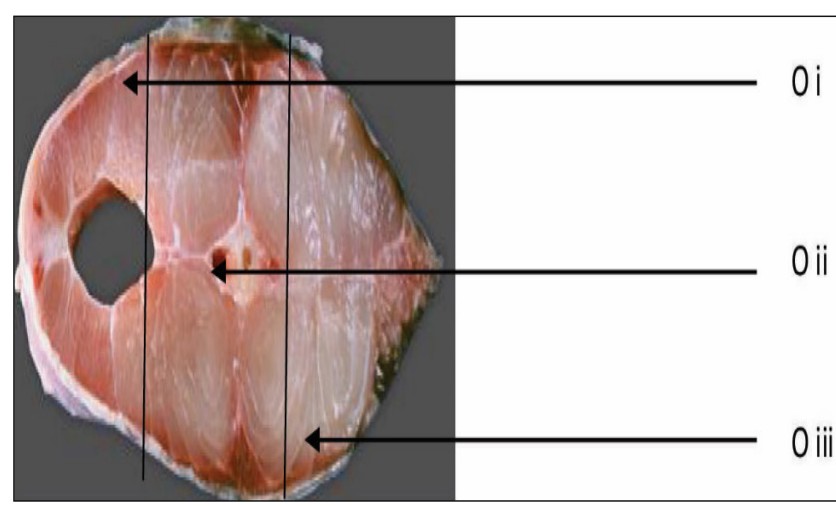

Fig: 3: Each sample fish were cut into 3 smaller pieces

Similarly, for salt marinated sample, took OS I, OS II, OS III with length $2.2^{\prime \prime}, 2.1 "$ \& 2.3 " and width were 1.5", $1.5^{\prime \prime}$ and 1.3" while weight of the samples were $48 \mathrm{gm}, 46$ gm and $52 \mathrm{gm}$. And lastly for turmeric \& salt marinated sample, took OST I, OST II, OST ${ }^{3}$ with length 2.5", 2.3" \& 2.1" and width were 1.6", 1.5" and 1.3" while weight of the samples were $50 \mathrm{gm}, 46 \mathrm{gm}$ and $45 \mathrm{gm}$.

\section{RESULTS AND DISCUSSION}

In this portion of the study we tried to check different possible means, by which the contaminated fish, especially with Salmonella spp, might be treated or processed for safer consumption. From that point of view, we had collected Rohu fish sample from a known source (Fishery Farm, Bagahata, Narshindi) where it could be expected to cultivate the fishes maintaining proper hygiene. Then we confirmed impact of various food processing measures, like salt and/or turmeric marinating and then boiling or frying, which we usually do in our households, before consuming the fish. The results of those experiments are described below.

\section{Detection of Salmonella in fresh fish (Negative control)}

Table 1: Detection of Salmonella in fresh fish (Negative control)

\begin{tabular}{llll}
\hline & & & \multicolumn{2}{c}{ Colony forming unit/gm } \\
Fish sample & Dilution & SPC & $N=\frac{\Sigma C}{V \times 1.1 \times d}$ \\
\hline \multirow{2}{*}{ F I } & $10^{1}$ & - & 0 \\
& $10^{2}$ & - & 0 \\
& $10^{3}$ & - & 0 \\
F II & $10^{1}$ & - & 0 \\
& $10^{2}$ & - & 0 \\
& $10^{3}$ & - & 0 \\
F III & $10^{1}$ & - & 0 \\
& $10^{2}$ & - & 0 \\
& $10^{3}$ & - & 0 \\
\hline
\end{tabular}

Absent $=(-)$ Present $=(+)$ 
Detection of Salmonella in Salmonella-loaded fish (Positive Control)

Table 2: Detection of Salmonella in Salmonella-loaded fish (Positive Control)

\begin{tabular}{|c|c|c|c|c|}
\hline \multirow{3}{*}{ Fish sample } & \multirow{3}{*}{ Dilution } & \multicolumn{2}{|r|}{ cfu/gm } & \multirow{3}{*}{$\begin{array}{l}\text { Average } \\
\text { cfu/gm }\end{array}$} \\
\hline & & SPC & $\Sigma C$ & \\
\hline & & & $V \times 1.1 \times d$ & \\
\hline \multirow{3}{*}{ FL I } & $10^{1}$ & + & $6.50 \times 10^{1}$ & \multirow{3}{*}{$2.26 \times 10^{3}$} \\
\hline & $10^{2}$ & + & $5.21 \times 10^{2}$ & \\
\hline & $10^{3}$ & - & $6.21 \times 10^{3}$ & \\
\hline \multirow{3}{*}{ FL II } & $10^{1}$ & + & $4.50 \times 10^{1}$ & \multirow{3}{*}{$1.89 \times 10^{2}$} \\
\hline & $10^{2}$ & - & $5.21 \times 10^{2}$ & \\
\hline & $10^{3}$ & - & 0 & \\
\hline \multirow{3}{*}{ FL III } & $10^{1}$ & - & $2.21 \times 10^{1}$ & \multirow{3}{*}{$0.74 \times 10^{1}$} \\
\hline & $10^{2}$ & - & 0 & \\
\hline & $10^{3}$ & - & 0 & \\
\hline
\end{tabular}

Absent $=(-)$ Present $=(+)$

Impact of oil fry $\left(400^{\circ} \mathrm{C}\right.$ after various kinds of fish processing)

\section{Group - A}

Table 3: Detection of Salmonella in without marinated fish

\begin{tabular}{|c|c|c|c|c|c|c|}
\hline \multirow[b]{2}{*}{ Fish sample } & \multirow[b]{2}{*}{ Dilution } & \multicolumn{5}{|c|}{ cfu/gm } \\
\hline & & Temp. $\left({ }^{\circ} \mathrm{C}\right)$ & Time & SPC & $N=\frac{\Sigma C}{V \times 1.1 \times d}$ & Average cfu \\
\hline \multirow{3}{*}{ FO I } & $10^{1}$ & & & + & $5.25 \times 10^{2}$ & \multirow{3}{*}{$5.25 \times 10^{2}$} \\
\hline & $10^{2}$ & & $1 \mathrm{~min}$ & - & 0 & \\
\hline & $10^{3}$ & & & - & 0 & \\
\hline \multirow{3}{*}{ FO II } & $10^{1}$ & & & + & $4.50 \times 10^{1}$ & \multirow{3}{*}{$4.50 \times 10^{1}$} \\
\hline & $10^{2}$ & 400 & $2 \mathrm{~min}$ & - & 0 & \\
\hline & $10^{3}$ & & & - & 0 & \\
\hline \multirow{3}{*}{ FO III } & $10^{1}$ & & & - & 0 & \multirow{3}{*}{0} \\
\hline & $10^{2}$ & & $3 \mathrm{~min}$ & - & 0 & \\
\hline & $10^{3}$ & & & - & 0 & \\
\hline
\end{tabular}

Absent $=(-)$ Present $=(+)$ 


\section{Group - B}

Table 4: Detection of Salmonella in Turmeric marinated fish

\begin{tabular}{|c|c|c|c|c|c|c|}
\hline \multirow{3}{*}{ Fish sample } & \multirow{3}{*}{ Dilution } & \multirow{3}{*}{ Temperature $\left({ }^{\circ} \mathrm{C}\right)$} & \multirow{3}{*}{ Time } & \multicolumn{2}{|r|}{ cfu/gm } & \multirow{3}{*}{$\begin{array}{l}\text { Average } \\
\text { cfu }\end{array}$} \\
\hline & & & & SPC & $N=\Sigma C$ & \\
\hline & & & & & $V \times 1.1 \times d$ & \\
\hline \multirow{3}{*}{ FOT I } & $10^{1}$ & & & + & $5.50 \times 10^{1}$ & $5.50 \times 10$ \\
\hline & $10^{2}$ & & $1 \mathrm{~min}$ & - & 0 & \\
\hline & $10^{3}$ & & & - & 0 & \\
\hline \multirow{3}{*}{ FOT II } & $10^{1}$ & & & + & $4.50 \times 10^{1}$ & $4.50 \times 10^{1}$ \\
\hline & $10^{2}$ & 400 & $2 \min$ & - & 0 & \\
\hline & $10^{3}$ & & & - & 0 & \\
\hline \multirow{3}{*}{ FOT III } & $10^{1}$ & & & - & 0 & 0 \\
\hline & $10^{2}$ & & $3 \min$ & - & 0 & \\
\hline & $10^{3}$ & & & - & 0 & \\
\hline
\end{tabular}

Absent $=(-)$ Present $=(+)$

Group - C

Table 5: Detection of Salmonella in Salt marinated fish

\begin{tabular}{|c|c|c|c|c|c|}
\hline \multirow{3}{*}{ Fish sample } & \multirow{3}{*}{ Dilution } & \multirow{3}{*}{ Temperature $\left({ }^{\circ} \mathrm{C}\right)$} & \multirow{3}{*}{ Time } & \multicolumn{2}{|r|}{ cfu/gm } \\
\hline & & & & SPC & $\Sigma C$ \\
\hline & & & & & $N=\overline{V \times 1.1 \times d}$ \\
\hline \multirow{3}{*}{ FOS I } & $10^{1}$ & \multirow{9}{*}{400} & \multirow{3}{*}{$1 \mathrm{~min}$} & + & $3.50 \times 10^{1}$ \\
\hline & $10^{2}$ & & & - & 0 \\
\hline & $10^{3}$ & & & - & 0 \\
\hline \multirow{3}{*}{ FOS II } & $10^{1}$ & & \multirow{3}{*}{$2 \mathrm{~min}$} & - & 0 \\
\hline & $10^{2}$ & & & - & 0 \\
\hline & $10^{3}$ & & & - & 0 \\
\hline \multirow{3}{*}{ FOS III } & $10^{1}$ & & \multirow{3}{*}{$3 \mathrm{~min}$} & - & 0 \\
\hline & $10^{2}$ & & & - & 0 \\
\hline & $10^{3}$ & & & - & 0 \\
\hline
\end{tabular}

Absent $=(-)$ Present $=(+)$ 


\section{Group -D}

Table 6: Detection of Salmonella in Salt and Turmeric marinated fish

\begin{tabular}{|c|c|c|c|c|c|c|}
\hline \multirow[b]{2}{*}{ Fish sample } & \multirow[b]{2}{*}{ Dilution } & \multirow[b]{2}{*}{ Temperature $\left({ }^{\circ} \mathrm{C}\right)$} & \multirow[b]{2}{*}{ Time } & \multirow[b]{2}{*}{ SPC } & \multicolumn{2}{|c|}{ Colony forming unit/gm } \\
\hline & & & & & $N=\frac{\Sigma C}{V \times 1.1 \times d}$ & $\begin{array}{l}\text { Average } \\
\text { cfu/gm }\end{array}$ \\
\hline \multirow{4}{*}{ FOST I } & $10^{1}$ & \multirow{9}{*}{400} & \multirow{3}{*}{$1 \mathrm{~min}$} & - & 0 & \\
\hline & $10^{2}$ & & & - & 0 & \\
\hline & $10^{3}$ & & & - & 0 & \\
\hline & $10^{1}$ & & \multirow{3}{*}{$2 \min$} & - & 0 & \\
\hline \multirow[t]{2}{*}{ FOST II } & $10^{2}$ & & & - & 0 & 0 \\
\hline & $10^{3}$ & & & - & 0 & \\
\hline \multirow{3}{*}{ FOST III } & $10^{1}$ & & \multirow{3}{*}{$3 \mathrm{~min}$} & - & 0 & \\
\hline & $10^{2}$ & & & - & 0 & \\
\hline & $10^{3}$ & & & - & 0 & \\
\hline
\end{tabular}

Absent $=(-)$ Present $=(+)$

\section{Impact of water boiling $\left(100^{\circ} \mathrm{C}\right)$ after various kinds of} fish processing

Like our previous test, here we have taken samples of Salt marinated, Turmeric marinated, Salt \& Turmeric marinated and raw fish and carried out similar process in boiled fish to ascertain presence of Salmonella. When we boiled the fish sample, we found that at 5 minute and 10 minutes' test of the first dilution of fried fish Salmonella was present. But, no Salmonella was found in the rest of the samples.

Raw fishes are highly perishable protein source that contain normal bacterial flora from their environment in addition to the contaminants occurred during harvesting and handling of the products. The living fishes carry populations of predominantly Gram-negative psychotropic bacteria on their external skin. Coliforms could be absent or present in very low density and Salmonella, Shigella, Vibrio and other enteric pathogens are usually not found as these organisms are not the normal flora of the fishes or of their environment (FAO, 1979).

The bacterial ecology of fish products is connected to environmental factors such as water pollution, anthropic activities, fish feed quality, hygienic procedures of slaughter, handling, transport, commercialization and storage conditions. In freshwater aquaculture, the microbial load in the water used for cultivation is closely connected to several factors such as bacterial ecology of supply water, environment, fish feed, soil and water. From this research it can be concluded that, to produce better quality fishes and to avoid public health risks due to fish borne disease outbreaks, it is necessary to follow the code of practices concerning fish production, handling of the catching, icing, post-harvesting procedure and storage. In the present study, Salmonella spp. were isolated from tested fish samples. So, further study should be conducted on genomic sequencing.

The fresh fish raw samples show absence of salmonella whereas the positive control which was salmonella loaded showed presence of salmonella in $1^{\text {st }}, 2^{\text {nd }}$ and $3^{\text {rd }}$ dilution. Without marinating fried fish showed salmonella in $1 \mathrm{~min}$, 2 min of $1^{\text {st }}$ dilution sample and 3 min sample showed no salmonella. In case of turmeric marinated fried fish, $1^{\text {st }}$ dilution of both 1 min and 2 min showed salmonella load. In case of salt marinated fried fish, the $1^{\text {st }}$ dilution of 1 min showed the presence of salmonella and no salmonella was present in salt and turmeric marinated fish. In case of boiled fish which was not marinate, salmonella was present only in $1^{\text {st }}$ dilution of both 5 and $10 \mathrm{~min}$. In case of boiled fish which was turmeric marinated, salmonella was present only in $1^{\text {st }}$ dilution of both 5 and $10 \mathrm{~min}$. In case of boiled fish which was salt marinated, salmonella was 


\section{Group -A}

Table 7: Detection of Salmonella in without marinated fish

\begin{tabular}{|c|c|c|c|c|c|c|}
\hline \multirow[b]{2}{*}{ Fish sample } & \multirow[b]{2}{*}{ Dilution } & \multirow[b]{2}{*}{$\begin{array}{l}\text { Temperature } \\
\left({ }^{\circ} \mathrm{C}\right)\end{array}$} & \multirow[b]{2}{*}{ Time } & \multicolumn{2}{|r|}{ cfu/gm } & \multirow[b]{2}{*}{ Average cfu/ gm } \\
\hline & & & & SPC & $N=\frac{\Sigma C}{V \times 1.1 \times d}$ & \\
\hline \multirow{3}{*}{ W I } & $10^{1}$ & \multirow{9}{*}{400} & \multirow{3}{*}{$5 \mathrm{~min}$} & + & $4.50 \times 10^{3}$ & \multirow[t]{3}{*}{$4.50 \times 10^{3}$} \\
\hline & $10^{2}$ & & & - & 0 & \\
\hline & $10^{3}$ & & & - & 0 & \\
\hline \multirow{3}{*}{ W II } & $10^{1}$ & & \multirow{3}{*}{$10 \mathrm{~min}$} & + & $2.50 \times 10^{2}$ & \multirow[t]{4}{*}{$2.50 \times 10^{2}$} \\
\hline & $10^{2}$ & & & - & 0 & \\
\hline & $10^{3}$ & & & - & 0 & \\
\hline \multirow{3}{*}{ W III } & $10^{1}$ & & \multirow{3}{*}{$15 \mathrm{~min}$} & - & 0 & \\
\hline & $10^{2}$ & & & - & 0 & \multirow[t]{2}{*}{0} \\
\hline & $10^{3}$ & & & - & 0 & \\
\hline
\end{tabular}

Absent $=(-)$ Present $=(+)$

\section{Group-B}

Table 8: Detection of Salmonella in Turmeric marinated fish

\begin{tabular}{|c|c|c|c|c|c|c|}
\hline Fish sample & Dilution & Temperature $\left({ }^{\circ} \mathrm{C}\right)$ & Time & SPC & $\begin{array}{l}\text { Colony forming unit/gm } \\
N=\frac{\Sigma C}{V \times 1.1 \times d}\end{array}$ & $\begin{array}{l}\text { Average } \\
\text { cfu/gm }\end{array}$ \\
\hline \multirow{3}{*}{ WT I } & $10^{1}$ & & & + & $4.50 \times 10^{2}$ & $4.50 \times 10^{2}$ \\
\hline & $10^{2}$ & & $5 \mathrm{~min}$ & - & 0 & \\
\hline & $10^{3}$ & & & - & 0 & \\
\hline \multirow{3}{*}{ WT II } & $10^{1}$ & & & + & $1.50 \times 10^{2}$ & $1.50 \times 10^{2}$ \\
\hline & $10^{2}$ & 400 & $10 \mathrm{~min}$ & - & 0 & \\
\hline & $10^{3}$ & & & - & 0 & \\
\hline \multirow{3}{*}{ WT III } & $10^{1}$ & & & - & 0 & \\
\hline & $10^{2}$ & & $15 \mathrm{~min}$ & - & 0 & 0 \\
\hline & $10^{3}$ & & & - & 0 & \\
\hline
\end{tabular}

Absent $=(-)$ Present $=(+)$ 


\section{Group-C}

Table 9: Detection of Salmonella in Salt marinated fish

\begin{tabular}{|c|c|c|c|c|c|c|}
\hline Fish sample & Dilution & $\begin{array}{l}\text { Temperature } \\
\left({ }^{\circ} \mathrm{C}\right)\end{array}$ & Time & SPC & $\begin{array}{l}\text { Colony forming unit/gm } \\
N=\frac{\Sigma C}{V \times 1.1 \times d}\end{array}$ & $\begin{array}{l}\text { Average } \\
\text { cfu/gm }\end{array}$ \\
\hline \multirow{4}{*}{ WS I } & $10^{1}$ & & \multirow{3}{*}{$5 \mathrm{~min}$} & + & $4.50 \times 10^{1}$ & \multirow{4}{*}{$4.50 \times 10^{1}$} \\
\hline & $10^{2}$ & & & - & 0 & \\
\hline & $10^{3}$ & & & - & 0 & \\
\hline & $10^{1}$ & & & - & 0 & \\
\hline \multirow[t]{3}{*}{ WS II } & $10^{2}$ & 400 & $10 \mathrm{~min}$ & - & 0 & \multirow[t]{3}{*}{0} \\
\hline & $10^{3}$ & & & - & 0 & \\
\hline & $10^{1}$ & & & - & 0 & \\
\hline \multirow[t]{2}{*}{ WS III } & $10^{2}$ & & $15 \mathrm{~min}$ & - & 0 & \multirow[t]{2}{*}{0} \\
\hline & $10^{3}$ & & & - & 0 & \\
\hline
\end{tabular}

Absent $=(-)$ Present $=(+)$

\section{Group-D}

Table 10: Detection of Salmonella in Salt and Turmeric marinated fish

\begin{tabular}{|c|c|c|c|c|c|}
\hline \multirow[b]{2}{*}{ Fish sample } & \multirow[b]{2}{*}{ Dilution } & \multirow[b]{2}{*}{ Temperature $\left({ }^{\circ} \mathbf{C}\right)$} & \multirow[b]{2}{*}{ Time } & \multicolumn{2}{|r|}{ Colony forming unit/gm } \\
\hline & & & & SPC & $N=\frac{\Sigma C}{V \times 1.1 \times d}$ \\
\hline \multirow{3}{*}{ WTS I } & $10^{1}$ & & & - & 0 \\
\hline & $10^{2}$ & & $5 \mathrm{~min}$ & - & 0 \\
\hline & $10^{3}$ & & & - & 0 \\
\hline \multirow{3}{*}{ WTS II } & $10^{1}$ & & & - & 0 \\
\hline & $10^{2}$ & 400 & $10 \mathrm{~min}$ & - & 0 \\
\hline & $10^{3}$ & & & - & 0 \\
\hline \multirow{3}{*}{ WTS III } & $10^{1}$ & & & - & 0 \\
\hline & $10^{2}$ & & $15 \mathrm{~min}$ & - & 0 \\
\hline & $10^{3}$ & & & - & 0 \\
\hline
\end{tabular}

Absent $=(-)$ Present $=(+)$

present only in $1^{\text {st }}$ dilution of both $5 \mathrm{~min}$. In case of boiled fish which was salt and turmeric marinated, no salmonella was present.

\section{CONCLUSION}

Although Bangladesh has changed her position from a "poor country" to a "developing country" but our main diet still includes rice and fish. Specially the children eat some common fishes daily. The common fishes include Rui. Bacteria can pass from foods, commonly raw foods to other foods. It can occur if foods touch directly, if one food drips on to another, if your hands, or utensils or equipment, such as knives or chopping boards, touch one 
food and then another. After touching raw foods, separate raw and cooked or 'ready-to-eat' foods hands to be washed. The knives and required utensils must be cleaned after preparing raw foods. Typhoid, diarrhea, lose motion due to attack from bacteria causes health lose all over the world. Salmonella species causes substantial morbidity, mortality and burden of disease globally. Infections with Salmonella species cause multiple clinical syndromes. We do not have technological advancement or the knowledge how to take care of lot of health issues. One of our main problems is less education among mass people. The less educated or the unfortunate one is more ignorant about the precautions that should be taken while cleaning, cooking and also in self-hygiene to stay away from Salmonella infection.

\section{Novelty statement}

Bangladesh is a developing country. Fish is our main source of protein. Being the main food, it is also a source of many diseases like typhoid, diarrhea, cholera, etc. My emphasis on my article is to find the condition under which the fishes are contaminated and a way how to consume them more safely.

\section{REFERENCES}

Shewan, J.M. 1961. The Microbiology of Sea-Water Fish. In: Fish as Food, Borgstrom, G. (Ed.). Academic Press, FL., pp: 487-560.

Geldreich, E.E. and Clarke, N.A. 1966. Bacterial pollution indicators in the intestinal tract of freshwater fish. Appl. Mibiol., 14(3): 429-.

Boyd, J.F. 1985. Pathology of the alimentary tract in Salmonella typhimurium food poisoning. Gut., 26(9): 935-944.

Finlay, B.B., Heffron, F. and Falkow, S. 1989. Epithelial cell surfaces induce Salmonella proteins required for bacterial adherence and invasion. Science, 243(48930): 940-943.
Galan, J.E. and Curtiss, R. 1989. Cloning and molecular characterization of genes whose products allow Salmonella typhimurium to penetrate tissue culture cells. Proc. Natl. Acad. Sci. USA., 86(16): 6383-6387.

Clarke, R.C. and Gyles, C.L. 1987. Virulence of wild and mutant strains of Salmonella typhimurium in ligated intestinal segments of calves, pigs, and rabbits. Am. J. Vet. Res., 48(3): 504-10.

Coombes, B.K., Coburn, B.A., Potter, A.A., Gomis, S., Mirakhur, K., Li, Y. and Finlay, B.B. 2005. Analysis of the contribution of Salmonella pathogenicity islands 1 and 2 to enteric disease progression using a novel bovine ileal loop model and a murine model of infectious enterocolitis. Infect Immun., 73(11): 7161-9.

Boyd, J.F. 1969. Salmonella typhimurium, colitis, and pancreatitis. Lancet, 2(7626): 901-902.

Franchi, L., Amer, A., Body-Malapel, M., Kanneganti, T.D., Ozoren, N., Jagirdar, R. Inohara, N., Vandenabeele, P., Bertin, J., Coyle, A., Grant, E.P. and Núñez, G. 2006. Cytosolic flagellin requires Ipaf for activation of caspase-1 and interleukin 1beta in salmonella-infected macrophages. Nat. Immunol., 7(6): 576-82.

Fierer, J. and Guiney, D.G. 2001. Diverse virulence traits underlying different clinical outcomes of Salmonella infection. J. Clin. Invest., 107(7): 775-780.

Coburn, B., Li, Y., Owen, D., Vallance, B.A. and Finlay, B.B. 2005. Salmonella enterica serovar yphimurium pathogenicity island 2 is necessary for complete virulence in a mouse model of infectious enterocolitis. Infect. Immun., 73(6): 3219-27.

Dybing, J.K., Walters, N. and Pascual, D.W. 1999. Role of endogenous interleukin-18 in resolving wild-type and attenuated Salmonella typhimurium infections. Infect. Immun., 67(12): 6242-6248.

Geldreich, E.E. and Clarke, N.A. 1966. Bacterial pollution indicators in the intestinal tract of freshwater fish. Appl. Micrbiol., 14(3): 429-437. 
